\title{
Effects of Starter Culture and Types of Bamboo Tubes on Microbiological and Shelf Life Characteristics of Buffalo Milk Banhor Chunga Doi- an Ethnic Product of India
}

\author{
S. Roy, T. Borpuzari, M. Raquib, S.M. Gogoi, A.K. Sharma
}

10.18805/ajdfr.DR-1762

\begin{abstract}
Background: The present research was undertaken to study the effects of yoghurt culture and bamboo tubes on the microbiological and shelf life attributes of curd prepared from buffalo milk in bamboo tubes (popularly known as "Banhor Chunga Doi" in Assam) under room temperature.

Methods: Banhor Chunga Doi was prepared using Jati and Jatie Makal bamboo tubes. Starter culture was added and the tubes were kept in ambient room temperature. The shelf-life of the set products was ascertained by objective assessment of $\mathrm{pH}$, titratable acidity and microbial load

Result: Amongst the 4 treatment groups, the samples of $\mathrm{B}(\mathrm{JB})$ i.e., Banhor Chunga Doi prepared from boiled and cooled buffalo milk and stored in tubes of Jati bamboo at room temperature for $5 \mathrm{~d}$ showed the highest $\mathrm{pH}$ value of $4.01 \pm 0.011$ with a corresponding least lactic acid content of $1.21 \pm 0.005 \%$. Amongst the 2 control and 4 treatment groups, the highest mean TVC of $8.69 \log _{10} \mathrm{cfu} / \mathrm{g} \pm 0.001$ was enumerated in the samples of SC (JB) which might be due to the addition of the starter culture at the dose level of approximately $6.86 \log _{10} \mathrm{cfu} / \mathrm{g}$ in the beginning of the production process. The starter culture added samples [SC (JB) and SC (JMB)] showed an increasing TVC up to $3^{\text {rd }}$ day of storage. Thereafter, the TVC of these samples decreased on $5^{\text {th }}$ day. The lowest mean TVC of $4.38 \pm 0.003 \log _{10} \mathrm{cfu} / \mathrm{g}$ was noted in the samples of $B(\mathrm{JMB})$ which is due to the thermal destruction of the contaminating microbes during boiling of the milk sample. The samples of the buffalo milk Banhor Chunga Doi that were not inoculated with the starter culture exhibited an increasing TVC from $1^{\text {st }}$ to the $5^{\text {th }} \mathrm{d}$ of storage at room temperature. Over the storage period, none of the Banhor Chunga Doi samples either from the control or the treatment groups were found to possess coliform organisms, Escherichia coli, Salmonella, Shigella, Staphylococcus aureus, yeast and moulds. The shelf life of the end product was found to be good for consumption upto 5 days with gradual decrease in $\mathrm{pH}$ values and concomitant increase in titratable acidity in all the treatment groups.
\end{abstract}

Key words: Bamboo tubes, Buffalo milk, Microbiology, Shelf life, Starter culture.

\section{INTRODUCTION}

Fermented milk products have been an integral part of human diet because of its improved sensory, nutritional, prophylactic as well as therapeutic properties. Indigenous traditional knowledge is generally employed in preparation of vast majority of the fermented milk products and the background microbiota of the milk is mostly relied upon to bring about fermentative changes in the milk which fail to guarantee uniformity in the sensory properties and shelflife of the product. The 'back slopping' technique is largely followed. Application of dairy starter cultures has the proven advantages of uniformity in products' quality, better shelflife, improved sensory qualities and over and above significant improvement in safety indices of the final product.

Over the years, the people of Assam have developed an ITK for fermentation of buffalo milk in bamboo tubes. The product is popularly known as "Banhor Chunga Doi". It is prepared by fermenting fresh, raw buffalo milk in a bamboo tube capped with either banana leaves or paddy straw at room temperature for few days. Fermentation is mostly relied upon on the background microflora of the milk, of the bamboo tube as well as the microflora of the banana leaves / paddy straw used for capping the bamboo tubes.
Department of Livestock Products Technology, College of Veterinary Science, Assam Agricultural University, Khanapara, Guwahati-781 022, Assam, India.

Corresponding Author: Sumi Roy, Department of Livestock Products Technology, College of Veterinary Science, Assam Agricultural University, Khanapara, Guwahati-781 022, Assam, India. Email: sumisumanroy@gmail.com

How to cite this article: Roy, S., Borpuzari, T., Raquib, M., Gogoi, S.M. and Sharma, A.K. (2021). Effects of Starter Culture and Types of Bamboo Tubes on Microbiological and Shelf Life Characteristics of Buffalo Milk Banhor Chunga Doi- an Ethnic Product of India. Asian Journal of Dairy and Food Research. DOI: 10.18805/ajdfr.DR1762.

Submitted: 15-06-2021 Accepted: 11-08-2021 Online: 09-09-2021

Spontaneous and uncontrolled fermentation takes place and therefore day to day variations in eating quality, safety indices and storage life of the product are common. Various types of locally available bamboo tubes, viz, Jati bamboo, Jatie makal bamboo and Kako bamboo tubes are used for doi production in Assam.

Shelf-life of Banhor Chunga Doi vary considerably due to uncontrolled production management. The types of 
Effects of Starter Culture and Types of Bamboo Tubes on Microbiological and Shelf Life Characteristics of Buffalo Milk...

bamboo may also have certain influence on the aroma and other eating quality attributes of the product. Since, addition of starter culture has been reported to enhance shelf-life of fermented milk with superior eating quality characteristics (Kiran et al., 2012), it may be an approach towards value addition to employ dairy starter culture in preparation of Banhor Chunga Doi to ensure products' uniformity with superior sensory attributes, increased shelf-life and safety indices for better marketability of the product.

Literature survey, however, revealed scanty information on the use of starter culture in production of Banhor Chunga Doi. Therefore, in the present study an attempt was made to study the effect of dairy starter culture and types of bamboo tubes on the microbiological quality and shelf life of buffalo milk Banhor Chunga Doi under room temperature storage.

\section{MATERIALS AND METHODS}

The study was undertaken in the laboratories of the Department of Livestock Products Technology and in the All India Coordinated Research Project on Post-Harvest Engineering and Technology, College of Veterinary Science, Assam Agricultural University, Khanapara Campus, Guwahati -781022 during the period from August, 2018 to February, 2019.

\section{Procurement of raw materials}

Fresh raw buffalo's milk and Jati and Jatie Makal bamboo tubes for the study was procured from the local market. The sizes of the Jati and Jatie Makal bamboo tubes were $40 \mathrm{~cm}$ x $6 \mathrm{~cm}$ and $40 \mathrm{~cm} \times 8 \mathrm{~cm}$, respectively.

\section{Starter culture}

Yoghurt culture NCDC 144 (mixed culture of Lactobacillus delbrueckeii ssp. bulgaricus and Streptococcus thermophilus) obtained from the National Dairy Research Institute, Karnal, Haryana-132001 was used in the study. Freeze dried culture was inoculated in reconstituted and sterilised skim milk (12\% $\mathrm{w} / \mathrm{v})$. Working cultures were maintained in skim milk, subcultured at weekly interval and the stock culture was maintained in nutrient agar slants. Stock culture was stored at (-) $20^{\circ} \mathrm{C}$ and sub-cultured at 3 month's interval. Active culture of sixteen to eighteen hour was prepared by inoculating the stock culture @ $2 \%$ in sterilised skim milk (12\% w/v). Repeated sub-culturing, at least three times, was done before using it as starter culture for preparation of Banhor Chunga Doi.

\section{Banhor Chunga Doi preparation}

Banhor Chunga Doi was prepared by following the standard technique given by Aneja et al. (2002) with slight modification (APPENDIX I). For the purpose, Jatiand Jatie makal bamboo tubes were used and filled with buffalo milk and allowed to set at room temperature.

Immediately after setting, the products were analysed for their microbiological quality. For shelf-life study, samples were kept at room temperature till spoilage. $\mathrm{pH}$, acidity and microbial load were assessed on fresh product ( $1^{\text {st }}$ day), $3^{\text {rd }}$ and $5^{\text {th }}$ day.

\section{Treatment groups}

The following treatment groups of Banhor Chunga Doi were prepared:

Control (JB) Raw buffalo milk in Jati bamboo tube.

Control (JMB) Raw buffalo milk in Jatie makal bamboo tube. Boiled (JB) Boiled and cooled buffalo milk in Jati bamboo tube.

Boiled (JMB) Boiled and cooled buffalo milk in Jatie makal bamboo tube.

SC (JB) Boiled and cooled buffalo milk+active starter culture of NCDC 144 [@ 1.5\% (v/v)] in Jati bamboo tube.

SC (JMB) Boiled and cooled buffalo milk + active starter culture of NCDC 144 [@ 1.5\% (v/v)] in Jatie makal bamboo tube.

Microbiological analysis of Banhor Chunga Doi and bamboo tubes

Microbiological analysis of Banhor Chunga Doi samples were done by standard method (Harrigan and McCance, 1976). Total viable count, coliform count and counts for Escherichia coli, Salmonella and Shigella, Staphylococcus aureus, yeast and moulds were enumerated by using appropriate media (Plate Count Agar, Endo Agar, Salmonella-Shigella agar, Mannitol Salt Agar Base and in Rose Bengal Chloramphenicol Agar Base, respectively) and optimum incubation conditions. Lactobacilli of bamboo tubes was also enumerated in Lactobacilli MRS Agar.

\section{Shelf-Life of Banhor Chunga Doi}

The shelf-life of the set products was ascertained by objective assessment of $\mathrm{pH}$ using digital $\mathrm{pH}$ meter (Model 780, Metrohm, Switzerland), titratable acidity by following the method of Atherton and Newlander (1977) and microbial load (Total Viable Count, coliform, Escherichia coli, Salmonella and Shigella, Staphylococcus aureus, yeast and mould counts) was enumerated by standard techniques given by Harrigan and McCance (1976).

\section{Statistical analysis}

Experimental data obtained from the experiment were analysed by using Randomised Block Design (RBD) and ANOVA was done with the help of SAS 9.4.

\section{RESULTS AND DISCUSSION}

\section{Enumeration of microorganism} Aerobic count of bamboo tubes

In the present study, nil lactobacilli were recorded in the bamboo tubes of all types (Table 1). However, some

Table 1: Total viable and lactobacilli count (Mean \pm Se) of bamboo tubes $\left(\log _{10} \mathrm{cfu} / \mathrm{Ml}\right)$.

\begin{tabular}{lccc}
\hline Bacteriological Count & $\begin{array}{c}\text { Jati } \\
\text { bamboo }\end{array}$ & $\begin{array}{c}\text { Jatie makal } \\
\text { bamboo }\end{array}$ & t-value \\
\hline Total viable count & $2.815 \pm 0.017$ & $2.780 \pm 0.040$ & 0.806 \\
Lactobacilli count & 0.00 & 0.00 & 0.00 \\
\hline
\end{tabular}




\section{APPENDIX I}

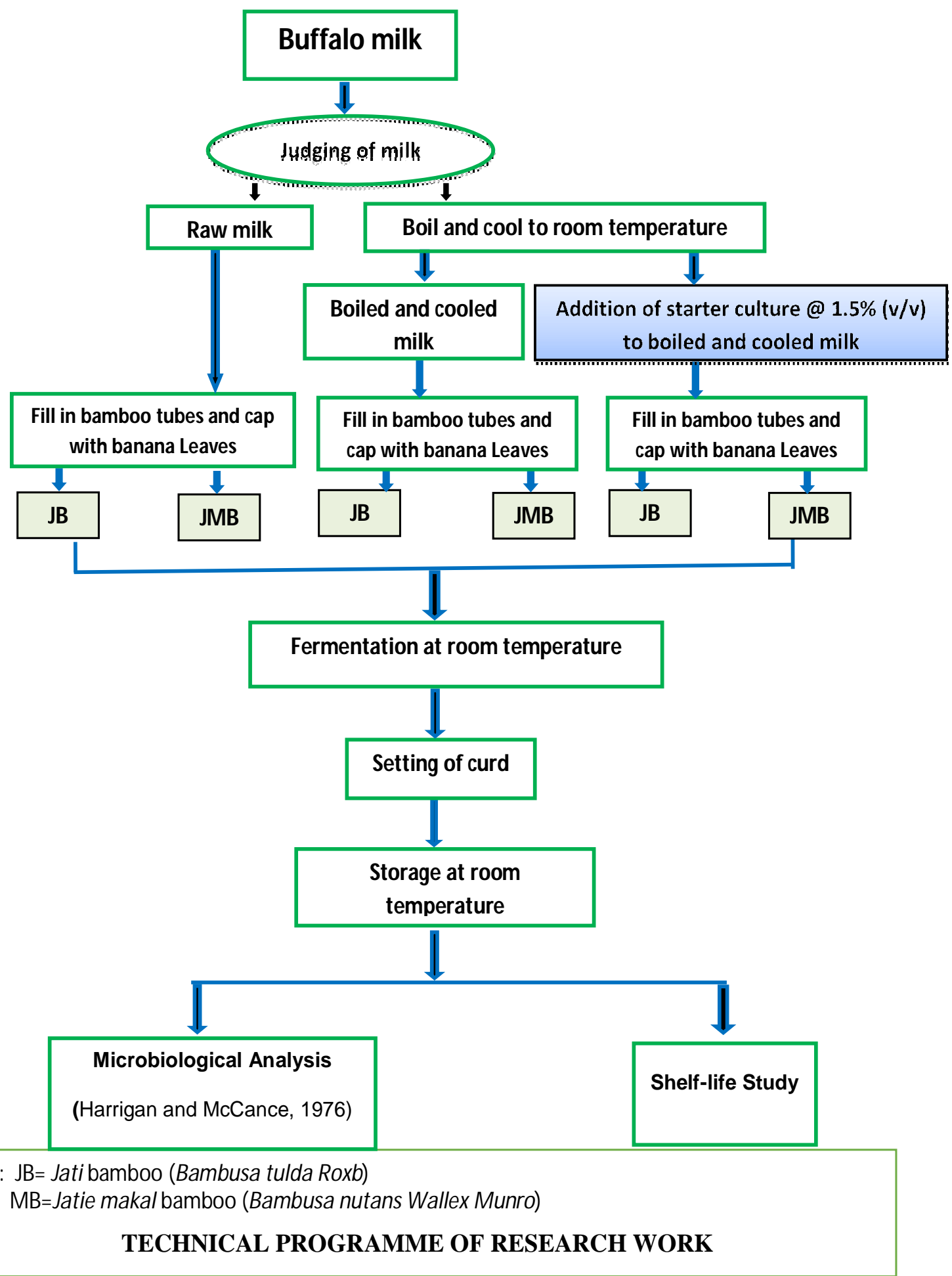




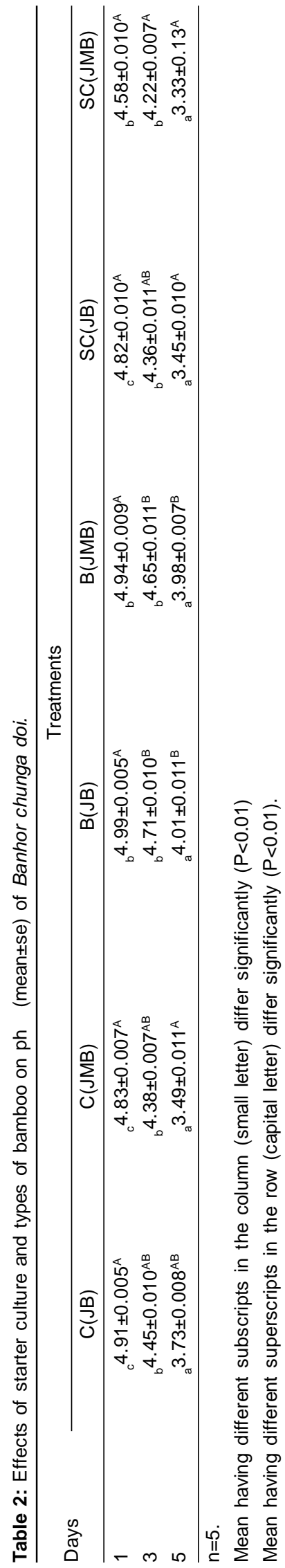

researchers have reported presence of $L A B$ in bamboo tubes (Puspawati et al., 2018).

\section{Shelf life}

Shelf life of the finished products were judged by assessing their $\mathrm{pH}$ values, titratable acidity and microbiological counts on $1^{\text {st }}, 3^{\text {rd }}$ and $5^{\text {th }}$ day of storage.

\section{$\mathrm{pH}$ and titratable acidity}

Mean $\mathrm{pH}$ values of all the treatment and control groups of Banhor Chunga Doi showed a decreasing trend during the entire storage period at ambient temperature. Ready products exhibited a variation in mean $\mathrm{pH}$ values between $4.58 \pm 0.01$ and $4.99 \pm 0.005$ on $1^{\text {st }}$ day which showed a further decrease till $5^{\text {th }}$ day of storage (Table 2). Among the treatment groups, SC added (JMB) product showed the least $\mathrm{pH}$ of $3.33 \pm 0.13$ on $5^{\text {th }}$ day. Such decline in $\mathrm{pH}$ values of finished product during storage was also reported by Sokolinska et al. (2004), Han et al. (2012) and Karsheva et al. (2013). This decrease in $\mathrm{pH}$ values may be presumed to be due to continued lactic acid bacterial fermentation during storage (Shah, 2000; Kailasapathy, 2006) as was indicated by increasing TVC in treatment groups - boiled (JB and JMB) and SC added boiled (JMB) products. The decreasing trend in $\mathrm{pH}$ in the present study may not only be due entirely to $\mathrm{LAB}$ but also may be due to proteolytic bacteria present naturally in the bamboo tubes and banana leaves used for capping the tubes (Nurmiati et al., 2018).

Analysis of variance (Table 3 ) of data on the effects of starter culture and types of bamboo on $\mathrm{pH}$ of Banhor Chunga Doi showed highly significant variations between treatments and days of storage while interaction effect between treatments and days of storage did not show any significant variation $(P>0.05)$.

A gradual increase in the acid content from $1^{\text {st }}$ to $3^{\text {rd }}$ day could be noted in all the groups between $0.96 \pm 0.009$ and $1.38 \pm 0.011$ while it was not observed in control (JB) and SC added JMB products (Table 4). This might be attributed to the production of lactic acid from lactose of milk by LAB present in raw milk or by SC being added to boiled and cooled milk during the fermentation process (Fadela et al., 2009). In general, boiled milk products prepared in both JB and JMB exhibited somewhat lesser acid content on $5^{\text {th }}$ day $(1.21 \pm 0.005$ and $1.23 \pm 0.004)$ as compared to control and SC added JB and JMB products (Table 4). This might be due to the effect of boiling the milk

Table 3: Analysis of variance of data on effects of starter culture and types of bamboo on ph of Banhor Chunga Doi.

\begin{tabular}{lcr}
\hline $\begin{array}{l}\text { Source of } \\
\text { variation }\end{array}$ & df & $\begin{array}{r}\text { Mean square of } \\
\text { dependent variable }\end{array}$ \\
\hline Treatment & 4 & $0.602991^{* *}$ \\
Day & 2 & $10.87011^{\star *}$ \\
Treatment x Day & 10 & 0.042326 \\
Error & 20 & 0.000433 \\
\hline
\end{tabular}

** Significant at $\mathrm{P}<0.01$. 


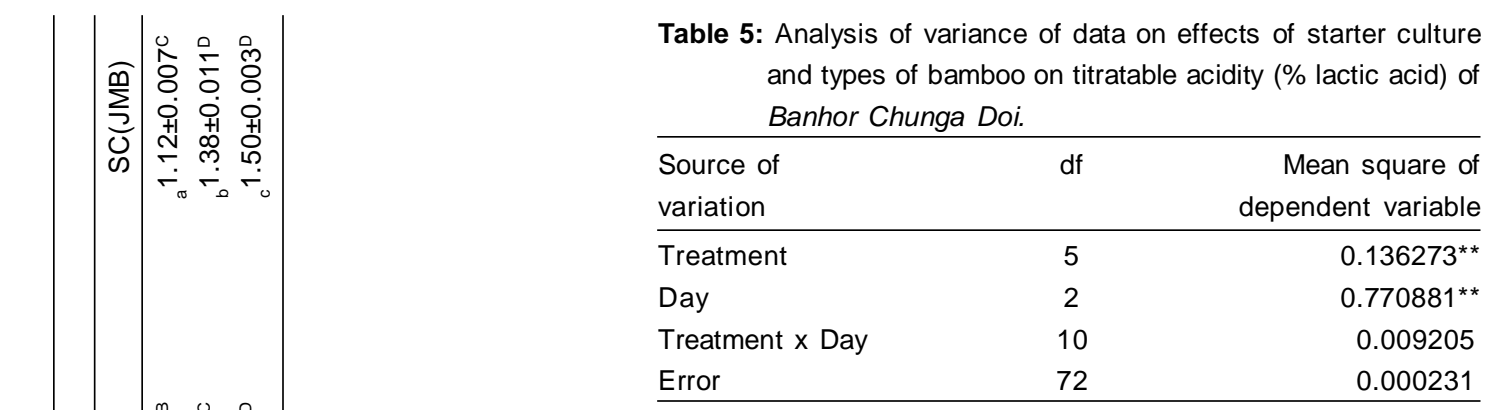

**Significant at $\mathrm{P}<0.01$.

before allowing it to undergo natural fermentation. These findings are in accordance to the findings of Metwally et al. (2011) who reported a reduction in bacterial count of buffalo milk by boiling, for 0.5 to $1 \mathrm{~min}$, from $7.8 \times 10^{9}$ to $2.26 \times 10^{3} \mathrm{cfu} /$ $\mathrm{ml}$ and $1.3 \times 10^{3} \mathrm{cfu} / \mathrm{ml}$, respectively. The titratable acidity of the finished product showed highly significant variations between treatments and days of storage while interaction effect between treatments and days of storage did not show any significant variation ( $P>0.05)$ (Table 5).

\section{Microbiological analysis}

A sharp increase in TVC of all the groups including the control groups was noted from $1^{\text {st }}$ to the $3^{\text {rd }}$ day of storage at ambient temperature between $4.380 \pm 0.003$ and $9.332 \pm 0.004$ (Table 6). Here after, irrespective of the bamboo types used, a decrease in TVC of both the control and SC added samples was recorded. This might be attributed to the fact that some of the organisms might have reached their stationary phage in their life cycle resulting in lesser count on $5^{\text {th }}$ day of storage. On the other hand, boiled JB and JMB samples showed a gradual increasing trend in TVC from $1^{\text {st }}$ to $5^{\text {th }}$ day of storage at ambient temperature (Table 6). Such variation in TVC of dahi samples might be due to the metabolites produced by SC or by other natural fermenting $L A B$ as well as their storage condition (Sivakumar and Kalaiarasu, 2010). Initial increase in TVC may be attributed to faster growth of LAB (Hamann and Marth, 1984). Effect of type of bamboo on TVC was also documented by Puspawati et al. (2018). Among the different bamboo tubes used, TVC of dadih samples prepared in dry petung bamboo samples, showed the maximum TVC of $9.4 \times 10^{9}$ to $1.5 \times 10^{10} \mathrm{cfu} / \mathrm{g}$. In general,a higher TVC in SC added treatment groups during the entire storage period was noted which might be due to the addition of SC@6.86 $\log _{10} \mathrm{cfu} / \mathrm{ml}$.

Analysis of variance (Table 7 ) of data on the effects of starter culture and types of bamboo on microbiological quality of Banhor Chunga Doi showed highly significant variations between treatment groups and days of storage at room temperature but interaction effect between treatments and days of storage did not show any significant variation $(P>0.05)$

Nil coliform, E. coli, Salmonella, Shigella, yeast and moulds in Banhor Chunga Doi samples indicate proper sanitary/ hygienic conditions followed during the production process as well as production of probable bacteriocin during 
Effects of Starter Culture and Types of Bamboo Tubes on Microbiological and Shelf Life Characteristics of Buffalo Milk...

Table 6: Effects of starter culture and types of bamboo on total viable count (Mean \pm Se) of Banhor Chunga Doi (log ${ }_{10}$ cfu/g) during storage (room temperature) *.

\begin{tabular}{|c|c|c|c|c|c|c|}
\hline \multirow{2}{*}{ Days } & \multicolumn{5}{|c|}{ Treatments } & \multirow[b]{2}{*}{$\mathrm{SC}(\mathrm{JMB})$} \\
\hline & $\mathrm{C}(\mathrm{JB})$ & $\mathrm{C}(\mathrm{JMB})$ & $\mathrm{B}(\mathrm{JB})$ & $\mathrm{B}(\mathrm{JMB})$ & $\mathrm{SC}(\mathrm{JB})$ & \\
\hline 1 & $\mathrm{a}^{7.833 \pm 0.002^{\mathrm{D}}}$ & $\mathrm{a}^{7.690 \pm 0.001^{c}}$ & $a^{4.431 \pm 0.002^{B}}$ & $a^{4.380 \pm 0.003^{A}}$ & ${ }_{a}^{8.690 \pm 0.001^{F}}$ & $a^{8.544 \pm 0.001^{E}}$ \\
\hline 3 & ${ }_{c}^{8.431 \pm 0.001^{D}}$ & $8.243 \pm 0.002^{c}$ & ${ }_{b}^{6.204 \pm 0.002^{B}}$ & $6.130 \pm 0.002^{A}$ & ${ }_{c} 9.332 \pm 0.004^{F}$ & ${ }_{c} 9.114 \pm 0.003^{\mathrm{E}}$ \\
\hline 5 & $8.013 \pm 0.003^{D}$ & ${ }_{b} 7.942 \pm 0.001^{c}$ & $6.455 \pm 0.002^{B}$ & $6.290 \pm 0.001^{A}$ & ${ }_{b}^{9.119 \pm 0.005^{F}}$ & $8.921 \pm 0.001^{\mathrm{E}}$ \\
\hline
\end{tabular}

Mean having different subscripts in the column (small letter) differ significantly $(\mathrm{P}<0.01)$.

Mean having different superscripts in the row (capital letter) differ significantly $(P<0.01)$.

*Coliform, E.coli, Salmonella, Shigella, Staphylococcus aureus, yeast and molds, anaerobic spore count not be detected.

Table 7: Analysis of variance of data on effects of starter culture and types of bamboo on total viable count of Banhor Chunga Doi $\left(\log _{10} \mathrm{cfu} / \mathrm{g}\right)$ during storage (room temperature).

\begin{tabular}{lcc}
\hline $\begin{array}{l}\text { Source of } \\
\text { Variation }\end{array}$ & df & $\begin{array}{c}\text { Mean Square of } \\
\text { Dependent Variable }\end{array}$ \\
\hline Treatment & 5 & $36.34025^{* *}$ \\
Day & 2 & $5.803846^{* *}$ \\
Treatment x Day & 10 & 1.614118 \\
Error & 72 & 0.0000271 \\
\hline
\end{tabular}

** Significant at $\mathrm{P}<0.01$

the fermentation process (Sivakumar and Kalaiarasu, 2010; Chowdhury et al., 2011; Igbabul et al., 2014).

\section{CONCLUSION}

From the study it could be concluded that good quality buffalo milk curd may be prepared by using Jati and Jatie makal bamboo tubes. The ITK on use of both Jati and Jatie makal bamboo tubes in preparation of Banhor Chunga Doi is validated. Boiling and cooling of the buffalo milk and addition of starter culture @1.5\% (v/v) prior to filling in bamboo tubes add value to the finished product in terms of microbiological attributes. Buffalo milk Banhor Chunga Doi had a shelf-life of $5 \mathrm{~d}$ at room temperature.

\section{Suggestion}

Since non-availability of suitable commercial yoghurt culture in the region is a hindrance in transfer of the technology to the traditional producers of Banhor Chunga Doi, development of a repository of dairy starter cultures and commercial production of suitable yoghurt cultures in the region may be a boon to the traditional producers in production of uniform quality Banhor Chunga Doi with superior sensory-, microbiological- and safety indices.

\section{ACKNOWLEDGMENT}

The authors express sincere gratitude and thankfulness to the Dean, Faculty of Veterinary Science, AAU, Khanapara, Guwahati-22, for providing the necessary facilities and financial aid to carry out the research programme successfully, Dr R.N. Borpuzari, Professor, Deptt. of Livestock Products Technology and Dr. J. Hussain, Asstt. Professor, Deptt. of Livestock Production and Management,
College of Veterinary science, AAU, Khanapara, Ghy-22 for extending help in writing of this manuscript.

\section{REFERENCES}

Aneja, R.P., Mathur, B.N., Chandan, R.C. and Banerjee, A.K. (2002). Technology of Indian Milk Products, New Delhi: A Dairy India Publication. 133-142.

Atherton, H.V. and Newlander, J.A. (1977). Chemistry and Testing of Dairy Products, $4^{\text {th }}$ Edn., AVI Publ. Co. Inc. Westport, Connecticut.

Chowdhury, N.A., Paramanik, Kamruzzaman and Zaman,W.(2011). Study on the Quality Assessment of Curd (Dahi), Locally Available in Bangladesh Market. World J. Dairy Food Sci. 6(1): 15-20.

Fadela, C., Abderrahim, C. and Ahmed, B. (2009). Physico Chemical and rheological properties of yoghurt manufactured with ewe's milk and skim milk. Afr. J. Biotechnol. 8: 1938-1942.

Hamann, W.T. and Marth, Elmer H. (1984). Survival of Streptococcus thermophilus and Lactobacillus bulgaricus in Commercial and Experimental Yoghurts. J Food Protect. 47(10): 781-786.

Han, Xue, Lee, Frank L., Zhang, Lanwei and Guo, M.R. (2012). Chemical composition of water buffalo milk and its lowfat symbiotic yoghurt development. Func. Foods in Health and Disease. 2(4): 86-106.

Harrigan, W.F. and McCance, M.E. (1976). Laboratory Methods in Food and Dairy Microbiology. Acad. Press, London.

Igbabul, B., Shember, J. and A. Julius (2014). Physicochemical, microbiological and sensory evaluation of yoghurt sold in Makurdi metropolis. Afr. J. Food. Sci. Technol. 5(6): 129-135.

Kailasapathy, K. (2006). Survival of free and encapsulated probiotic bacteria and their effect on the sensory properties of yoghurt. LWT- Food Sci. Technol. 39(10): 1221-1227 (Abstr.)

Karsheva, M., Paskov, V., Tropcheva, R., Georgieva, R. and Danova, S. (2013). Physicochemical parameters and rheological properties of yoghurts during the storage. J. Chem. Technol. Metall. 48(5): 483-488.

Kiran, K.A. Usha., Appaiah, K.A., Anu and Appaiah, Sushma (2012). Extension of Shelf Life of Curd - An Indian Fermented Milk By using a new isolate of Brevibacillus brevis strain as Starter culture. Innov. Romanian Food Biotechnol. 10: 48-55. 
Effects of Starter Culture and Types of Bamboo Tubes on Microbiological and Shelf Life Characteristics of Buffalo Milk...

Metwally, Ahmed M.M., Dabiza, Nadia M.A., El-Kholy, Wagih I. and Sadek, Zeinab I. (2011). The effect of boiling on milk microbial contents and quality. J. Ame. Sci. 7(2): 110114.

Nurmiati, N., Periadnadi, P., Alamsyah, F. and Sapalina, F. (2018). Characterization and potential of acid fermentative and proteolytic natural microflora in several products of traditional Dadih from LembahGumanti District West Sumatra, Indonesia. Int. J. Curr. Microbiol. Appl. Sci. 7(3): 3151-3163.

Puspawati, N.N., Sugitha, I.M. and danDuniaji, A.S. (2018). Application and Characterization of Dadih from different kinds of bamboo plants (Bam

Biol. Agric. Healthcare. 8(12).
Shah, N.P. (2000). Probiotic bacteria: Selective enumeration and survival in dairy foods. J. Dairy. Sci. 83(4): 894-907.

Sivakumar, N. and Kalaiarasu, S. (2010). Microbiological approach of curd samples collected from different locations of Tamil Nadu, India. Int. J. Curr. Res. 2: 27-30.

Sokolinska, D.C., Michalski, M.M. and Pikul, J. (2004). Role of the proportion of yoghurt bacterial strains in milk souring and the formation of curd qualitative characteristics. Bull. Vet. Inst. Pulawy. 48: 437-441 (cited by Omola et al., 2014). 